international scientific unions and the Science Co-operation Offices established during the War, it indicates how the features of both are combined in the Field Science Co-nperation Offices, and then describes briefly the actual work of the four Offices so far established in Latin-America, East Asia, the Middle East and South Asia. Some account is given of the way in which these Offices have stimulated the establishment of regional research institutes and assisted in scientific reconstruction. Appendixes listing inquiries received, both as to subject and source, indicate the extent to which the four Offices are at present being used and the nature of the work, while details of the staff of the Offices and a bibliography are also appended.

\section{Haslemere Educational Museum}

THE educational value of historical and other charts arranged on a space-for-time plan has been realized since 1770 when Dr. Joseph Priestley pub. lished a synopsis of history arranged in this manner. The value of such charts in museum teaching was not recognized before 1888 . In that year Sir Jonathan Hutchinson expounded, in his home museum at Inval, geology and human history by the space-for-time method. In the following year outlines of the historical and geological space-for-time schedules were given in a paper on the Haslemere Educational Museum contributed by Sir Jonathan to government educational reports. Similar outlines found a place in the Museum guide-book issued in 1912. The guidebook has long been out of print, and now an outline has been prepared, to meet the wish frequently expressed by visitors to the Museum and teachers, for a hand-guide to the space-for-time large wall schedules in the geology and history galleries. The outlines may be obtained from the Curator of the Museum, price 2s. 6d.

\section{Sorawak Museum Journal}

AFTER a gap of twelve years in publication, the Sarauak Museum Journal reappears in a new format, with illustrations, under the editorship of Mr. Tom Harrison, curator" of the Museum. As before, the Journal is chiefly devoted to anthropology, ethnology and archæology, and this is indeed inevitable in such a country as Borneo, where hitherto the published information on such subjects is meagre. In the present issue is a group of papers dealing with the material aspects of Borneo culture, followed by articles on customs and beliefs, including one written in Malay. Another group deals with linguistic problems, and a smaller concluding section with zoological and botanical subjects.

\section{The Night Sky in February}

Fuls moon occurs on Feb. 2d. 22h. $16 \mathrm{~m}$., U.T., and new moon on Feb. 16d. 22h. 53m. The following conjunctions with the mon take place: Feb. 5d. 10h., Saturn 0.4 ${ }^{\circ}$ N.; Feb. 7d. 02h., Mars $4^{\circ}$ N.; Feb. 14d. 18h., Mercury $5^{\circ} \mathrm{N}$; ; Feb. 14d. 22h., Venus $13^{\circ} \mathrm{N}$. In addition to these conjunctions with the moon, Mercury is in conjunction with Venus on Feb. 16d. 05h., Mercury being $8.4^{\circ} \mathrm{S}$. Mercury is a morning star, rising about $1 \frac{1}{2}$ hours before the sun on February 1 and less than half an hour before the sun at the end of the month, but is not an easy olject to observe during the twilight. Venus, which was in inforior conjunction on January 31 , can be seen as a morning star from about the middle of February, rising at $5 \mathrm{~h} .40 \mathrm{~m}$. and $4 \mathrm{~h} .55 \mathrm{~m}$. at the middle and end of the month, respectively. The stellar magnitude increases rapidly during February, from $-3 \cdot 2$ to $\mathbf{- 4 \cdot 2}$, due to the comparatively rapid increase in the area of the visible portion of the illuminated disk after inferior conjunction. Mars rises at $22 \mathrm{~h}$. $06 \mathrm{~m}$., $21 \mathrm{~h} .18 \mathrm{~m}$. and $20 \mathrm{~h} .18 \mathrm{~m}$., at the beginning, middle and end of the month, respectively. It moves eastward away from $\gamma$ Virginis until February 12 when it is stationary, and then it approaches the star to which it is very close at the end of the month. Jupiter, in conjunction with the sun on February 3, is unobservable during the month. Saturn rises early in the night and can be observed a little east of $\sigma$ Leonis, to which it draws closer, so that at the end of the month the planet and the star appear close to each other. The rings of Saturn are not conspicuous at present. Occultations of stars brighter than magnitude 6 are as follows: Feb. 5d. 0lh. $52 \cdot 3 \mathrm{~m}$., $\chi$ Leon. $(R)$; Feb. 5d. 22h. $25 \cdot 9 \mathrm{~m} ., \beta$ Virg. $(R) . R$ refers to reappearance, and the latitude of Greenwich is assumed.

\section{Announcements}

Sir Henry Dale has been elected president of the British Council in succession to Lord Riverdale, who has resigned for private rensons. Sir Henry was a member of the Executive Committee of the Council during 1943-49 and chairman of its Science Advisory Committee during 1942-49.

Prof. D. Thoday, professor of botany in the University College of North Wales, Bangor, has been appointed professor of plant physiology in the Furouk I University, Alexandria, Egypt.

Prof. W. Davis, emeritus professor of textiles, University College, Nottingham, has been elected an honorary life member of the Textile Institute. Prof. Davis became a member of the Institute in 1910, and served continuously as a member of its Council during 1926-49.

British Chemicals and Biologicals, Ltd., 43 Regent Street, Loughborough, announce that they are now in a position to supply 60 per cent hydrazine hydrate in large amounts. Besides its use in the laboratory, hydrazine hydrate finds many industrial applications, mostly as a reducing agent, but also in cases where the liberation of nitrogen gas is useful.

THE American Society for the Study of Sterility is offoring an annual award of 1,000 dollars known as the Ortho Award for an essay on the result of some clinical or laboratory research pertinent to the field of sterility. The essay will appear on the programme of the forthcoming meeting of the Society to be held in San Francisco during June 24 and 25. Full particulars may be obtained from the Secretary, Dr. Walter W. Williams, 20 Magnolia Terrace, Springfield, Massachusetts; essays must be in his hands by April 1, 1950.

Beginning with the January 1950 issue, some changes take place in the monthly Bibliography of Industrial Diamond Applications, issued hy the Industrial Diamond Information Bureau, 32-34 Hol. born Viaduct, London, E.C.1. References to the articles abstracted are now arranged according to suggestions of the Abstracting Services Consultative Committee of the Royal Society, and their titles are printed in bold letters so that an easier survey is possible. The Billiography is sent free of charge to those interested technically or commercially in industrial diamonds. 